\title{
Elimination of locus-specific inter-individual variation in quantitative PCR
}

\author{
Jinxiu Shi, Qiang Liu, Vu Q. Nguyen, and Steve S. Sommer \\ City of Hope National Medical Center, Duarte, CA, USA
}

BioTechniques 37:934-938 (December 2004)

Robust dosage PCR (RD-PCR), a duplex and quantitative PCR, detects large heterozygous deletions and duplications in genomic DNA samples. RD-PCR amplifies an endogenous internal control and a target locus. Two of six RD-PCR assays behaved anomalously due to lower yields specific to the targets. The variability was eliminated by heat treatment of the genomic DNA samples in $2 \times$ TE solution at $90^{\circ} \mathrm{C}$ for 10 min. Heat treatment improves the utility of RD-PCR and may be generally helpful in multiplex PCR quantitation. The mechanism by which heat treatment eliminates inter-individual variation is unclear. The variability is not associated with DNA extraction methods, RNA contamination, or solution protein contamination, but may reflect inhibition from tightly bound chromatin proteins.

\section{INTRODUCTION}

Quantitation is essential for detection of large genomic duplications or deletions. Quantitative PCR has been achieved with external controls (1-3), competitive PCR with an internal dosage control (4-6), and multiplex PCR (7-11).

Quantitation of gene dosage remains a challenge, and it is known that multiplex PCR is sensitive to DNA quality $(12,13)$. Impurities in DNA samples can exert their effects by altering the efficiency of amplification in the exponential phase and the plateau phase of one or more segments. In addition, point mutations downstream of the primer within the amplified region can inhibit amplification $(14,15)$.

Robust dosage PCR (RD-PCR), a duplex quantitative PCR, was developed recently for the rapid and accurate detection of large heterozygous deletions and duplications $(16,17)$. RD-PCR amplifies an endogenous internal control and target locus. The internal control has a known gene copy number per cell, while the target has an unknown dosage number per cell. The ratio of yield (ROY) is directly proportional to the ratio of the two input templates, so the copy number of the target gene can be obtained from the ROY and the known copy number of the internal control.

When multiple RD-PCR assays were developed, significant inter-individual variation occurred in two regions of the $M E C P 2$ gene. This variation was easily eliminated by heating the genomic DNA samples in $2 \times$ TE solution (20

Table 1. List of Primer Pairs and PCR Segments

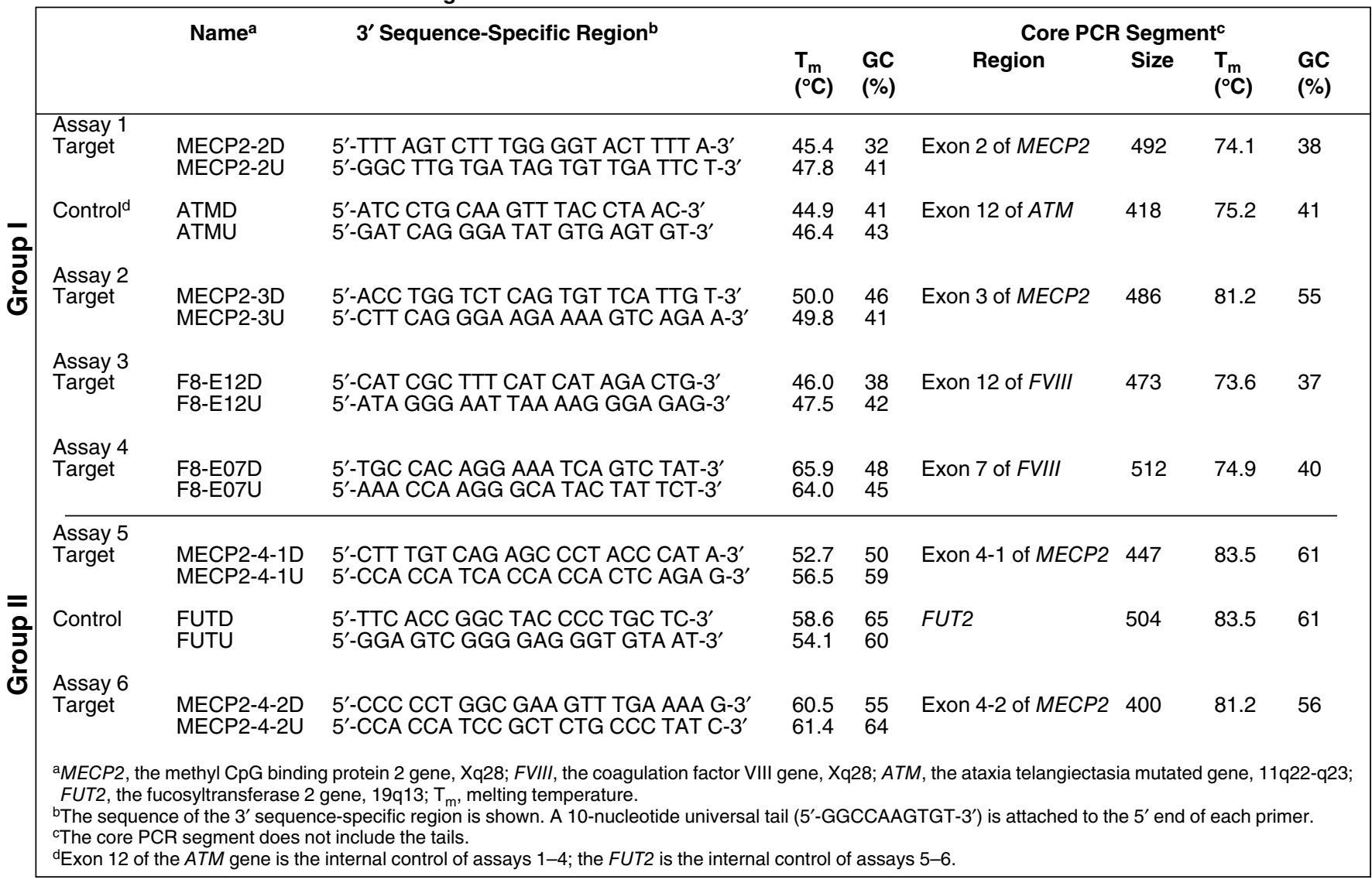




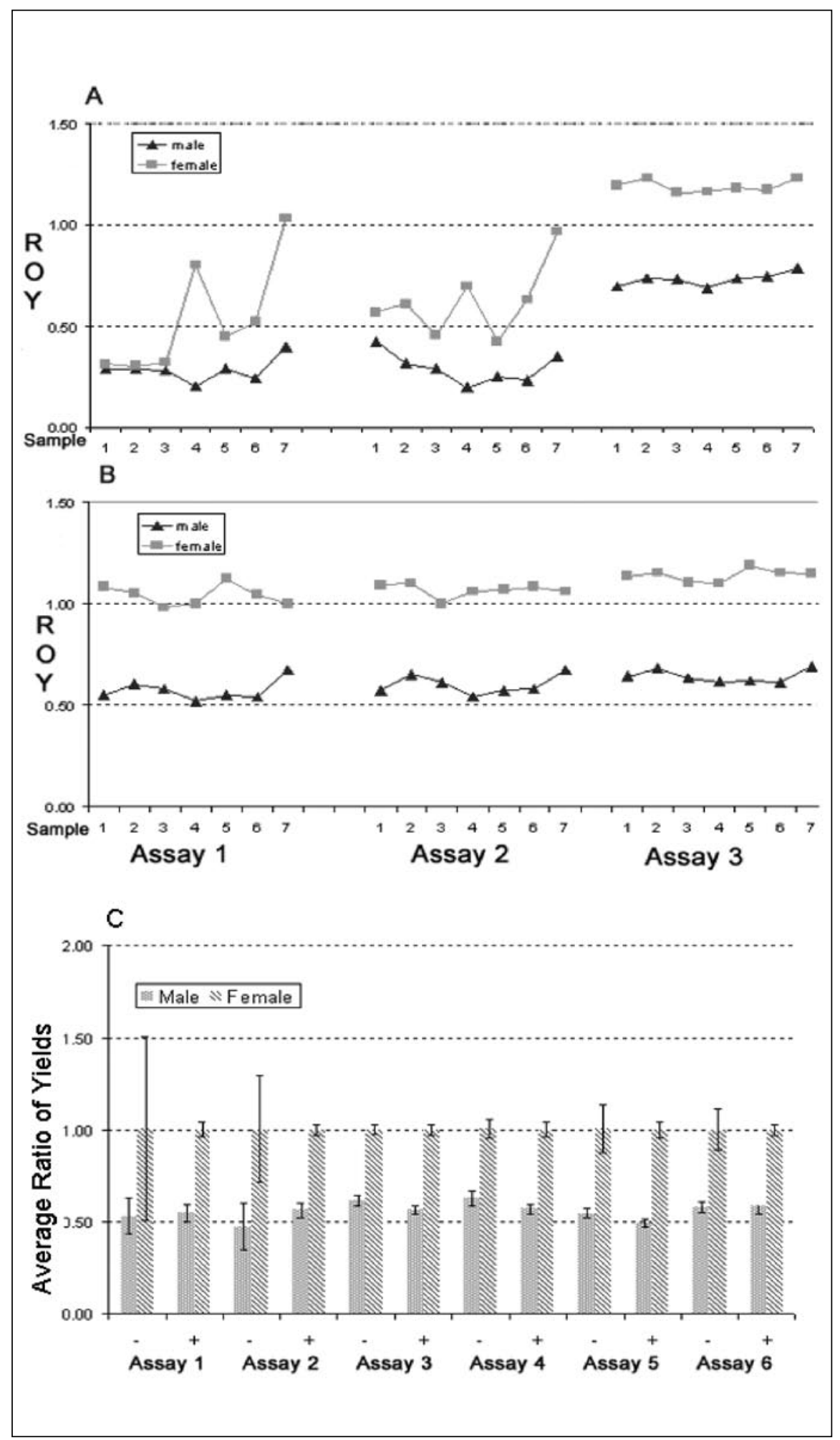

Figure 1. Ratio of yields (ROYs) in robust dosage PCR (RD-PCR) assays 1, 2, and 3 and the average and standard deviation of ROYs for all six RD-PCRs. Seven samples of each gender for each of assays 1,2, and 3 were analyzed with and without heat treatment. Female and male samples are indicated with squares (high) and triangles (low), respectively. The results of assays 4-6 are similar to assay 3 and not shown. (A) Without heat treatment. (B) With heat treatment. (C) X-axis shows each assay. Y-axis shows the average and standard deviation of the ROYs obtained from seven individual DNA samples of each gender. The average ROYs of females were normalized to 1.0 for comparison. -, without heat treatment; +, with heat treatment.
$\mathrm{mM}$ Tris-HCl, $1 \mathrm{mM}$ EDTA, $\mathrm{pH} 8.0$ at $25^{\circ} \mathrm{C}$ ) at $90^{\circ} \mathrm{C}$ for $10 \mathrm{~min}$.

\section{MATERIALS AND METHODS}

\section{Genomic DNA Samples}

Genomic DNA was prepared from peripheral blood by the PUREGENE ${ }^{\circledR}$ DNA Isolation kit (Gentra, Minneapolis, MN, USA), the standard phenol/chloroform protocol (18), or the Super Quick Gene DNA extraction kit (Analytical Genetic Testing Center, Denver, CO, USA). The samples were extracted and stored at $-20^{\circ} \mathrm{C}$ for $0-10$ years.

\section{Sample Pretreatment}

DNA concentrations were measured by UV spectrophotometer at $260 \mathrm{~nm}$ and adjusted to a working concentration of $30 \mathrm{ng} / \mu \mathrm{L}$ in $2 \times$ TE. Note that $1 \times$ TE eliminates the inter-individual variation, but decrease the yields. DNA samples were pretreated at $90^{\circ} \mathrm{C}$ for 10 min and then placed at $4^{\circ} \mathrm{C}$ until the $\mathrm{RD}-\mathrm{PCR}$ assays were performed. Other pretreatments were also performed (see Results and Discussion).

\section{RD-PCR Assay}

Six assays were designed (Table 1) according to Liu et al. (16) except for a shorter $5^{\prime}$ universal tail $\left(5^{\prime}\right.$ GGCCAAGTGT-3'). Each assay contained a target and an internal control segment. The assays were divided into two groups (group I and II) depending on whether the ATM or FUT gene was used as the autosomal control segment. Group I had four assays with GC contents ranging from $36.6 \%$ to $55 \%$; group II had two assays with GC content of $61 \%$ and $56 \%$.

The PCR mixtures contained a total volume of $25 \mu \mathrm{L}$ : $1 \times$ Expand $^{\mathrm{TM}} \mathrm{High}$ Fidelity buffer \#3 (Roche Applied Science, Indianapolis, IN, USA), 4.5 $\mathrm{mM} \mathrm{MgCl} 2,200 \mu \mathrm{M}$ of each dNTP for group I, or $3.0 \mathrm{mM} \mathrm{MgCl}{ }_{2}$ and 150 $\mu \mathrm{M}$ dGTP/50 $\mu \mathrm{M}$ deaza-dGTP, 200 $\mu \mathrm{M}$ of each other dNTPs, and $10 \%$ dimethylsulfoxide (DMSO) for group II, $0.1-0.2 \mu \mathrm{M}$ of each pair of primers, 1 U Platinum Taq DNA polymerase (Invitrogen, Carlsbad, CA, USA), and 
1 U Platinum Taq DNA polymerase High Fidelity (Invitrogen), $0.5 \mu \mathrm{g}$ of bovine serum albumin (BSA), and $60 \mathrm{ng}$ of genomic DNA. The cycling entailed denaturation at $94^{\circ} \mathrm{C}$ for $15 \mathrm{~s}$, annealing at $55^{\circ} \mathrm{C}$ for group I or $65^{\circ} \mathrm{C}$ for group II for $30 \mathrm{~s}$, and elongation at $72^{\circ} \mathrm{C}$ for $1 \mathrm{~min}$ for 23 cycles with a GeneAmp ${ }^{\circledR}$ PCR System 9700 (Applied Biosystems, Foster City, CA, USA).

\section{Quantitation}

Twelve microliters of PCR product were electrophoresed through a standard 2\% agarose gel. Gels were stained in $0.2 \mu \mathrm{g} / \mathrm{mL}$ ethidium bromide for $1 \mathrm{~h}$ and scanned by the Typhoon ${ }^{\mathrm{TM}}$ 9410 Imager (Amersham Biosciences, Piscataway, NJ, USA) with the following parameters: focal plane $=$ $+3 \mathrm{~mm}$; laser wavelength $=$ green, 532 $\mathrm{nm}$; emission filter $=610 \mathrm{BP} 30$; photomultiplier voltage $=600 \mathrm{~V}$; pixel size $=$ $100 \mu \mathrm{m}$; and sensitivity $=$ normal.

ImageQuant ${ }^{\mathrm{TM}}$ software (Amersham Biosciences) was used to quantitate the PCR yield. Net signal of a band was obtained by subtracting the local background. The ROY is calculated by dividing the target net signal by the internal control net signal. For normalization, the ROY of the patient sample was divided by the average ROY of the females (17).

\section{RESULTS AND DISCUSSION}

\section{Locus-Specific Assay Variability}

Six RD-PCR assays were performed using genomic DNA samples from seven males and seven females. In assays 1 and 2, significant interindividual variation occurred (Figure 1A).

When exon 2 of the $M E C P 2$ gene was amplified along with exon 12 of the $A T M$ gene as a control (assay 1), the product yields of the target were reduced among individual genomic DNA samples, while the yield of the control was similar among samples. ROYs varied from 0.30 to 1.03 in female samples and 0.20 to 0.40 in male samples (Figure 1A). The standard deviations were 0.28 in female samples and 0.06 in male samples. For 
Table 2. Pretreatments of DNA Samples

\begin{tabular}{|c|c|c|c|}
\hline \multicolumn{3}{|c|}{ Genomic DNA Treatment } & \multirow[b]{2}{*}{ Variation Elimination } \\
\hline $\begin{array}{c}\text { Temperature } \\
\left({ }^{\circ} \mathrm{C}\right)\end{array}$ & Time & Additive & \\
\hline 90 & $10 \mathrm{~min}$ & - & Yes \\
\hline 56 & $2 \mathrm{~h}$ & - & No \\
\hline 56 & $16 \mathrm{~h}$ & - & No \\
\hline 56 & $16 \mathrm{~h}$ & Proteinase $\mathrm{K}(2 \mathrm{mg} / \mathrm{mL})^{\mathrm{a}}$ & Yes \\
\hline 37 & $1 \mathrm{~h}$ & RNase $A(0.2 \mathrm{mg} / \mathrm{mL})^{\mathrm{b}}$ & No \\
\hline 20 & - & Membrane filtration $^{c}$ & No \\
\hline \multicolumn{4}{|c|}{$\begin{array}{l}\text { a2 } \mathrm{mg} / \mathrm{mL} \text { of Proteinase } \mathrm{K} \text {, incubated at } 56^{\circ} \mathrm{C} \text { overnight without the } 90^{\circ} \mathrm{C} \text { inactivation step. } \\
\text { b0.2 } \mathrm{mg} / \mathrm{mL} \text { of RNase } \mathrm{A} \text {, incubated at } 37^{\circ} \mathrm{C} \text { for } 1 \mathrm{~h} \text { and then followed by application of the QIAamp } \\
\text { DNA Blood mini kit (Qiagen, Valencia, CA, USA) to remove RNase A. } \\
\text { 'Removal of minimal solution contamination by filtration (Vivaspin } 500 \text { Polyethersulfone; } 300,000 \\
\text { MWCO; Vivascience AG, Hanover, Germany). }\end{array}$} \\
\hline
\end{tabular}

Table 3. Inter-Individual Variability and Its Elimination in Assay 1

\begin{tabular}{|c|c|c|c|c|c|c|}
\hline \multirow[b]{2}{*}{ Sample } & \multicolumn{3}{|c|}{ Control } & \multicolumn{3}{|c|}{ Target } \\
\hline & $-a$ & + & Heat Effect ${ }^{b}$ & - & + & Heat Effec \\
\hline \multicolumn{7}{|l|}{ Male } \\
\hline 1 & $0.83^{c}$ & 0.83 & 1.00 & 0.24 & 0.46 & 1.92 \\
\hline 2 & 1.01 & 1.03 & 1.02 & 0.29 & 0.62 & 2.14 \\
\hline 3 & 1.20 & 1.20 & 1.00 & 0.33 & 0.69 & 2.09 \\
\hline 4 & 1.28 & 1.20 & 0.94 & 0.26 & 0.62 & 2.38 \\
\hline 5 & 1.08 & 0.93 & 0.86 & 0.31 & 0.51 & 1.65 \\
\hline 6 & 1.09 & 0.90 & 0.83 & 0.26 & 0.49 & 1.88 \\
\hline 7 & 1.40 & 1.17 & 0.84 & 0.56 & 0.78 & 1.39 \\
\hline \multicolumn{7}{|l|}{ Female } \\
\hline 1 & 0.49 & 0.43 & 0.88 & 0.15 & 0.45 & 3.00 \\
\hline 2 & 0.44 & 0.43 & 0.98 & 0.13 & 0.45 & 3.46 \\
\hline 3 & 0.53 & 0.58 & 1.09 & 0.17 & 0.57 & 3.35 \\
\hline 4 & 0.51 & 0.51 & 1.00 & 0.41 & 0.51 & 1.24 \\
\hline 5 & 0.38 & 0.33 & 0.87 & 0.17 & 0.37 & 2.18 \\
\hline 6 & 0.54 & 0.47 & 0.87 & 0.28 & 0.49 & 1.75 \\
\hline 7 & 0.37 & 0.37 & 1.00 & 0.38 & 0.38 & 1.00 \\
\hline \multicolumn{7}{|c|}{$\begin{array}{l}\text { a-, without heat treatment; }+ \text {, with heat treatment. } \\
\text { bHeat effect is indicated as the ratio of the product yield with heat to product yield without heat. } \\
\text { 'The absolute amount of net signal of the amplified segment in an arbitrary unit, } \times 10^{7} \text {. }\end{array}$} \\
\hline
\end{tabular}

exon 3 of the $M E C P 2$ gene with the internal control of exon 12 of the ATM gene (assay 2), similar variation was observed (Figure 1A).

The inter-individual variability in the other assays 3-6 was low and not significant. As an example, the ROYs in assay 3 are listed in Figure 1.

The assay variability seen in assays 1 and 2 occurred with genomic DNA extracted by either the PUREgENe DNA Isolation kit, the phenol/chloroform method, or the Super Quick Gene DNA extraction kit (data not shown).

\section{Elimination of Locus-Specific Assay Variability}

Initially, treatment of genomic DNA with Proteinase $\mathrm{K}$ at $56^{\circ} \mathrm{C}$ for $16 \mathrm{~h}$ eliminated the assay variability. Subsequent experiments revealed that simply incubating the sample at $90^{\circ} \mathrm{C}$ for 10 min eliminated assay variability, while the variability was not eliminated by RNase treatment, treatment at $56^{\circ} \mathrm{C}$ at 2 or $16 \mathrm{~h}$, or with membrane filtration (Table 2). After heat treatment in $2 \times \mathrm{TE}$ at $90^{\circ} \mathrm{C}$ for $10 \mathrm{~min}$, the genomic DNA samples were amplified by RD-PCR assays $1-6$. The product yields of the target and control were quantitated, and the ROYs were then obtained. The average ROYs and standard deviation of each assay before and after the heat treatment are listed in Figure 1C.

Assay deviations were due to variable lower product yield of the $M E C P 2$ targets 
and not the control segment. In RD-PCR assay 1 , the product yields of the target were greatly increased by heat treatment, up to 3.46-fold, among individual genomic DNA samples. The yield of the control changes little, varying from 0.83- to 1.09-fold (Table 3). Thus, ROYs were greatly increased to $0.52-0.67$ in the male samples and $0.98-1.12$ in the female samples (Figure 1B). The standard deviations of ROY were 0.05 in the male samples and 0.04 in the female samples, showing that heat treatment makes the assay more consistent and eliminates the inter-individual variation. Similar results were observed in assay 2 (Figure 1B). The same experiments were repeated to confirm the results in both assays.

Similar results were obtained from genomic DNAs extracted by the phenol/chloroform method and the Super Quick Gene DNA extraction kit (data not shown). Heat treatment has also been used in eight subsequent assays; all worked well with little interindividual variation despite the use of samples extracted with the PUREgEne, phenol/chloroform, and Super Quick Gene methods (17).

The mechanism of the inter-individual variation and its elimination is unclear. When genomic DNA was serially diluted by 2-, 4-, 8-, 16-, 32-, and 64-fold and amplified for 30 cycles in assay 1, the anomalous ratios remained, suggesting that the inhibition was closely associated with the genomic DNA. We speculate that certain high-affinity DNA binding proteins may remain after extraction and may exert a subtle effect that is detected when dosage analysis is performed.

Conceivably, other genomic regions might resist $90^{\circ} \mathrm{C}$ for $10 \mathrm{~min}$. More work is needed to determine whether longer incubation with or without proteinase or other enzymatic treatment is necessary to remove inhibitors from certain regions. Ultimately, a pretreatment of DNA may facilitate robust multiplexed amplification throughout the genome. From a practical protocol of view, it may be prudent to treat with Proteinase $\mathrm{K}$ under general hydrolytic conditions for $2 \mathrm{~h}$, followed by $90^{\circ} \mathrm{C}$ heat inactivation in $2 \times \mathrm{TE}$ solution, in case there are any bound proteins that can survive $90^{\circ} \mathrm{C}$ heat treatment.

In conclusion, heat treatment is necessary at some loci for accurate measurement of dosage by RD-PCR. It may be necessary for multiplex amplifiable probe hybridization (MAPH), multiplex ligation-dependent probe amplification (MLPA), and other methods of assessing dosage $(19,20)$. Inhibitory amplification at certain segments also has implications for whole genome amplification techniques, such as multiple displacement amplification (MDA) and degenerate oligonucleotide prime PCR (DOP-PCR), in which quantitative representation might be an issue (21-23). The general utility of pretreatment of multiplex PCR and the mechanism of heat pretreatment require further study.

\section{COMPETING INTERESTS STATEMENT}

The authors declare no conflicts of interest.

\section{REFERENCES}

1.Heid, C.A., J. Stevens, K.J. Livak, and P.M. Williams. 1996. Real time quantitative PCR. Genome Res. 6:986-994.

2.Oka, S., K. Urayama, Y. Hirabayashi, K. Ohnishi, H. Goto, K. Mitamura, S. Kimura, and K. Shimada. 1990. Quantitative analysis of human immunodeficiency virus type-1 DNA in asymptomatic carriers using the polymerase chain reaction. Biochem. Biophys. Res. Commun. 167:1-8.

3.Wilke, K., B. Duman, and J. Horst. 2000. Diagnosis of haploidy and triploidy based on measurement of gene copy number by real-time PCR. Hum. Mutat. 16:431-436.

4.Ballagi-Pordany, A. and K. Funa. 1991. Quantitative determination of mRNA phenotypes by the polymerase chain reaction. Anal. Biochem. 196:89-94.

5.Telenti, A., P. Imboden, and D. Germann. 1992. Competitive polymerase chain reaction using an internal standard: application to the quantitation of viral DNA. J. Virol. Methods 39:259-268.

6.Wang, A.M., M.V. Doyle, and D.F. Mark. 1989. Quantitation of mRNA by the polymerase chain reaction [published erratum appears in Proc. Natl. Acad. Sci. USA 1990 Apr;87(7):2865]. Proc. Natl. Acad. Sci. USA 86:9717-9721.

7.Abbs, S. and M. Bobrow. 1992. Analysis of quantitative PCR for the diagnosis of deletion and duplication carriers in the dystrophin gene. J. Med. Genet. 29:191-196.

8.Kellogg, D.E., J.J. Sninsky, and S. Kowk. 1990. Quantitation of HIV-1 proviral DNA relative to cellular DNA by the polymerase chain reaction. Anal. Biochem. 189:202-208.

9.Mansfield, E.S. 1993. Diagnosis of Down syndrome and other aneuploidies using quantitative polymerase chain reaction and small tandem repeat polymorphisms. Hum. Mol. Genet. 2:43-50.

10.Pertl, B., U. Weitgasser, S. Kopp, P.M. Kroisel, J. Sherlock, and M.Adinolfi. 1996. Rapid detection of trisomies 21 and 18 and sexing by quanti- tative fluorescent multiplex PCR [published erratum appears in Hum. Genet. 1996 Nov;98(5):631] [see comments]. Hum. Genet. 98:55-59.

11.Poropat, R.A. and G.A. Nicholson. 1998. Determination of gene dosage at the PMP22 and androgen receptor loci by quantitative PCR [see comments]. Clin. Chem. 44:724-730.

12.Chamberlain, J.S., R.A. Gibbs, J.E. Ranier, and C.T. Caskey. 1989. Multiplex PCR for the diagnosis of Duchenne muscular dystrophy, $\mathrm{p}$. 272-281. In M. Innis, D. Gelfand, J. Sninsky, and T. White (Eds.), Academic Press, Orlando.

13.Yau, S.C., M. Bobrow, C.G. Mathew, and S.J. Abbs. 1996. Accurate diagnosis of carriers of deletions and duplications in Duchenne/Becker muscular dystrophy by fluorescent dosage analysis. J. Med. Genet. 33:550-558

14.Liu, Q., E.C. Thorland, and S.S. Sommer. 1997. Inhibition of PCR amplification by a point mutation downstream of a primer. BioTechniques 22:292-298

15.Barnard, R., V. Futo, N. Pecheniuk, M. Slattery, and T. Walsh. 1998. PCR bias toward the wild-type k-ras and p53 sequences: implications for PCR detection of mutations and cancer diagnosis. BioTechniques 25:684-691.

16.Liu, Q., X. Li, J.S. Chen, and S.S. Sommer. 2003. Robust dosage-PCR for detection of heterozygous chromosomal deletions. BioTechniques 34:558-568.

17.Nguyen, V.Q., J.X. Shi, Q. Liu, and S.S. Sommer. Robust dosage (RD)-PCR protocol for the detection of heterozygous deletions. BioTechniques 37:360-364.

18.Gustafson, S., J.A. Proper, E.J.W. Bowie, and S.S. Sommer. 1987. Parameters affecting the yield of DNA from human blood. Anal. Biochem. 165:294-299.

19.Armour, J.A., C. Sismani, P.C. Patsalis, and G. Cross. 2000. Measurement of locus copy number by hybridisation with amplifiable probes. Nucleic Acids Res. 28:605-609.

20.Schouten, J.P., C.J. McElgunn, R. Waaijer, D. Zwijnenburg, F. Diepvens, and G. Pals. 2002. Relative quantification of 40 nucleic acid sequences by multiplex ligation-dependent probe amplification. Nucleic Acids Res. 30:e57.

21.Dean, F.B., S. Hosono, L. Fang, X. Wu, A.F. Faruqi, P. Bray-Ward, Z. Sun, Q. Zong, et al. 2002. Comprehensive human genome amplification using multiple displacement amplification. Proc. Natl. Acad. Sci. USA 99:5261-5266.

22.Yan, J., J.N. Feng, and S.S. Sommer. 2004. Assessment of multiple displacement amplification (MDA) in molecular epidemiology. BioTechniques 37:136-143.

23.Telenius, H., N.P. Carter, C.E. Bebb, M. Nordenskjold, B.A. Ponder, and A. Tunnacliffe. 1992. Degenerate oligonucleotide-primed PCR: general amplification of target DNA by a single degenerate primer. Genomics 13:718-725.

Received 23 April 2004; accepted 27 July 2004.

Address correspondence to Steve S. Sommer, Director, Departments of Molecular Genetics and Molecular Diagnosis, City of Hope National Medical Center, Duarte, CA 910103000,USA.e-mail: sommerlab@coh.org 